\title{
The realm of continued emergence: The semiotics of George Herbert Mead and its implications to biosemiotics, semiotic matrix theory, and ecological ethics
}

\author{
Jorge Conesa Sevilla \\ Sleep Research Laboratory, The University Hospital of Bern \\ 3010 Bern, Switzerland \\ e-mail: ecopsicologie@yahoo.fr
}

\begin{abstract}
This examination of the often-inaccessible work and semiotics of George Herbert Mead focuses first on his pivotal ideas of Sociality, Consciousness, and Communication. Mead's insight of sociality as forced relatedness, or forced semiosis, appearing early in evolution, or appearing in simple systems, guarantees him a foundational place among biosemioticians. These ideas are Mead's exemplar description of multiple referentiality afforded to social organisms (connected to his idea of the generalized other), thus enabling passing from one umwelt to another, with relative ease. Although Mead's comprehensive semiosis is basically sound, and in concordance with modern and contemporary semiotics (and biosemiotics), it nevertheless lacks a satisfactory explanation of how conscious organisms achieve passing into new frames of reference. Semiotic Matrix Theory (SMT), its pansemiosis, describes falsifiable existential and cognitive heuristics of recognizing Energy requirements, Safety concerns and Possibility or Opportunity as "passing" functions. Finally, another type of emergence, ecoethics, is an embedded constant in biosemiosis. Not all semiosis is good semiosis, not all text is good text. Because our species is moving away from ancient biosemiosis and interrelatedness, this historicity, even ductile enough to invent synthetic semiosis or capricious umwelten, is facing the ecological reality and consequences of an overly anthropocentric text.
\end{abstract}


Tarantula: an insect whose bite is only cured by musick.

Melvyn Bragg's (2003: 213) entry and selection from Johnson's Dictionary (1755)

\section{Introduction}

It is an understatement to write that Mead's idea of sociality, and the mechanism of passing from umwelt to umwelt, are underused and understudied in biosemiotics today. With notable interpretations and exceptions to his contributions in general (see Wiley 1994; HarriesJones 1995; Kilpinen 2002), a neglected obligation to his crucial ideas is due partly to the intractability of Mead's text, often promising to continue in development where some of his ideas seem to walk a step further but no more, or suddenly stopping altogether, his freedom to produce additional text restricted due to his multiple academic and administrative responsibilities. ${ }^{1}$ The antiquated and modern term sociality, perhaps an unfortunate choice and label today, seems also so biased toward purely human semiosis, thus turning off potential biosemiotic readers in search of a biological synthesis.

Without deciphering what Mead meant by this term and, in general, with the apparent lack of relevance of Mead to biosemiotics, judging by the smaller ratio of his name in references to the names of other turn-ofthe-20th-century semioticians, in my opinion, has forced many contemporary writers to almost reinvent the "Mead Wheel". Specifically, if sociality is understood as he meant it, forced and pervasive, even inescapable, relatedness or semiosis, it provides an additional historical foundation for understanding biosemiotics proper, from endosemiosis to the human text. This is clearly illustrated when Arthur Murphy, a better interpreter of Mead than I, while trying to summarize Mead's communicative processes, says, "[...] the appearance of mind is only the culmination of that sociality which is found throughout the universe".

1 My paraphrase of John Dewey's personal evaluation of Mead's literary productivity in his prefatory remarks in The Philosophy of the Present, 1934a.

This universal and biosemiotic sounding description was written in 1932, a good seventy or so years before Jesper Hoffmeyer's Signs of Meaning in the Universe, in 1996. This comparison is made partly out of respect to J. Hoffmeyer's work and also because his name is associated with a canonical-now in biosemiotics providing a useful historical frame of reference. 
From endosemiotical-hormonal to human communication, Mead's concept of sociality, in tandem with his ideas and definitions of consciousness and communication, leaves little doubt that he was thinking of a grander biosemiosis while finally being canonized by history as the father of American sociology.

These words are obviously a tease of a more complex and synergetic semiosis that must explain all three concepts to present-day biosemioticians. It may be difficult to do justice, in this short examination, to all of Mead's writings, in which, in fragmentary manner, these concepts are used as the foundations of other elemental ideas. So I have opted instead to focus on The Philosophy of the Present (Mead 1930, 1932) as the most cited source and text for further analysis and discussion, yet other references and works will be cited. In the next section, I will try to illustrate in broad strokes, how sociality, consciousness, and communication are intimately connected, thus, once again, anticipating the writings of present day non semiotician, semiotician, and biosemiotician scholars alike. Section Three will connect all three concepts of sociality, consciousness, and of communication, if not in a logical system, at least into a coherent definition and semiosis that exemplifies what evolved semiosis could look like.

\section{Living with more or less consciousness: When is a 'thing' really a part of its Umwelt?}

"Always", might answer Mead, with the rest of biosemiotics, at least since the moment it became an organism. But there are differences and degrees of differences of existential embeddedness and the ability to extract meaning from different umwelten. Depending on the organism's evolution of consciousness and the ability to communicate with gestures or signs whose meanings are constantly derived from existential doings; depending on the degree of embeddedness and the ease with which an organism passes from umwelt to umwelt; then its mind can reach a certain threshold referred to earlier as multiple referentiality, on in Mead's term, the capacity for continued emergence.

These abilities, which Mead (1932) traces in evolutionary and relativity theory terms, as he understood them, finally place the very construction and manipulation of a 'self' within and as part of all the 
objects found in the umwelt. That is, when an organism is capable of referring to itself as an object among other objects, utilizes the sensations and experiences in reference to its umwelten, and is able to communicate the meanings of all these interactions to itself as well as to others, then that organism has acquired consciousness in Mead's (Mead 1932: 82) interpretation of this concept: “[...] the organism responds to itself as affected by a tree and at the same time to the tree as the field of possible interactions".

The interpretative participation of the 'self' emerging from and always embedded in a social universe dominates Mead's semiotics. The earlier allusion of the Batesonian phrase describing, in a pithy phrase we have all made into a slogan, the condition of interpretation, 'a difference which makes a difference' (Bateson 1979), would mean for Mead the following:

Signification has [...] two references, one to the thing indicated, and the other to the response, to the instance and to the meaning of the idea. It denotes and connotes. When the symbol is used for the one, it is a name. When it is used for the other, it is a concept. But it neither denotes nor connotes except, when in form at least, denotation and connotation are addressed both to a self and to others, when it is in a universe of discourse that is oriented with reference to a self. If the gesture simply indicates the object to another, it has no meaning to the individual who makes it, nor does the response which the other individual carries out become a meaning to him [...]. (Mead 1922: 246)

In short, the "difference" that would make a difference for Mead is that of a social entity that has internalized its social umwelt entirely, knows itself as a SELF, and within the province of this self, assumes universal interpretation of its broadcasted sign. This is the beginning of multiple referentiality, or the beginning of a theory of mind (Premack, Woodruff 1978).

In achieving multiple referentiality, and while addressing the human condition specifically, social beings are able to internalize the roles of others into a meta-schema that Mead made famous: The Generalized Other. Many books and articles written across different disciplines have elaborated upon, co-opted and attempted to deconstruct Mead's concept of the generalized other. Mead's concept anticipates or stands side by side with Piaget's (1932, 1972; or Vygotsky's beginning of social 'otherness thought', 1934), depending how one interprets history, emphasis on intelligence being predicated on the ability to take on the perspective of the other; tracing its 
development of scheme from reflexes to circular reactions to egocentrism, and beyond, to formal operations.

'Theory of Mind' researchers and theorists (Premack, Woodruff 1978; Woodruff, Premack 1979; Dennett 1983; Whiten, Byrne 1988; Byrne, Whiten 1988; Dennett 1991; Byrne, Tomasello 1995; Whiten 1996 - as well as detractors — see Heyes 1993; 1998) must always pay tribute to Mead in some fashion or another, and the generalized other, by any other pseudonym or novel coinage, whether apes do it, rats do it, or human children after the age of four do it, establishes intelligence as that capacity to somehow internalize the thinking of the other for any number of social and personal uses from deceit to altruistic empathy. Speaking of altruism, and extending Piaget's and Mead's ideas into the realm of moral reasoning, Kohlberg (1981) seeks and is able to demonstrate with empirical confirmation to Piaget's (1932) and his original intuitions that the abilities in perspective-taking and higher social consciousness set the stage for higher rational ethical thought.

More recently, with the increased focus on Emotional Intelligence (Goleman 1995), the idea of the generalized other can be placed on a practical and even empirically testable continuum that even Mead might approve of, beginning with the total neglect of the other as being significant to one's own selfish survival, proceeding further in development to familiarity with someone, continuing perhaps into tolerance for someone, graduating into sympathy and finally having empathy for others. Even within our own species, the higher end of this ethical continuum, as the many mansions and umwelten of possibilities of relatedness, is not achieved universally or consistently as Kohlberg's later data show (Colby et al. 1987).

A more important reason for revisiting Mead's triple conception of sociality, consciousness and communication, in addition to paying tribute to his foundational ideas, is that in his thinking there is in a solid base and independent confirmation that a mind that evolves in rich social contexts is nicely suited to: (1) extending the range of relatedness to such a fine point where it becomes the other; (2) that this now social mind is obligated to communicate the meanings derived from perceiving itself and using the capacity to be the other embedded in ever changing umwelten; and (3) that this mind so embedded in a social (objectively external and/or internalized) realm and exposed to a myriad of interactive opportunities has the potential to grow consciousness so 
as to integrate, no devour, umwelten that are truly extant to other less embedded organisms, as Piaget suggested (1972). ${ }^{3}$

\section{2a. Consciousness and sociality}

For Mead the journey of a mind on the way to acquiring consciousness ends up being a communicative and thus semiotic odyssey. $\mathrm{He}$ speaks of a first prerequisite of consciousness as an organism selects a new umwelt at will based on its own organismic needs and sensitivities and amalgamates this ability of selection with the new environment, resulting in further interaction possibilities in the newly forming umwelt. Of this process he writes:

[...] its first characteristic [the characteristics of a mind acquiring consciousness] is consciousness, that emergent which arises when the animal passes from the system in which it formerly existed to an environment that arises through the selectiveness of its own sensitivity, and thus to a new system within which parts of its own organism and its reactions to these parts become parts of its environment. (Mead 1932: 84)

The intimacy and degree of subjective participation in Mead's rendition of a functional circle marks him as a biosemiotic thinker of note when he underlies the importance of this embeddedness:

[...] the systems to which I have referred are in all cases interrelations between the organism and the world that reveal itself in an environment, determined by its relationship to the organism. Any essential change in the organism brings with it a corresponding change in the environment. (Mead 1932: 84)

The next step in minds acquiring consciousness is due both to sensorial and cognitive peculiarities that place the interpreter in a Peircian triad (Peirce 1916/1966) in a situation of mental reflection. In Mead's own words, "this next step is reached with the dominance of

3 But realistically speaking, the majority of social agents cannot pull this off, and humans, in our example, are more ergodic than non-ergodic, thus being limited to only finite sets of relatedness by their genotypic and phenotypic boundaries, and by their experiential and psychological experiences and limitations.

4 Or even mark him as an ecopsychologist like Kurt Lewin (1935; 1936; 1939; 1951) expressing a similar, non-topological description of Life Space. 
the distance senses and the delayed responses to these". In contemporary terms, a 300 millisecond delay between processing a distal stimulus and its final cognitive recognition, plus additional computation time in higher order, intermodal associative cortex, in communicative animals, offers or enforces a reflective capacity that I believe Mead finds to be crucial for the emergence of consciousness.

The final step in the acquisition of consciousness occurs when, "the characters of the environment constitute the stuff out of which values and meanings later arise when these characters can be isolated though gestures in communication". Therefore, Mead links consciousness itself with valuative communicative processes. Another way to encapsulate this process, as I understand Mead, is to say that consciousness is a semiosis on a grander scale, of meaningful and mediated (through communicative exercises) existential responses with a sense of historicity. ${ }^{6}$ This final leap, according to Mead, opens the door for an appreciation of universals, a signature of evolved consciousness.

Furthermore, it is important to highlight the fact that Mead is perfectly aware of the distinction between consciousness and Selfconsciousness, and I believe the final step he refers to in the acquisition of consciousness is really the possession of Self-consciousness. This is clear to me, when, for example, we read him in Mind, Self, and Society making this distinction:

It is the social process of influencing others in a social act and then taking the attitude of the others aroused by the stimulus, and then reacting in turn to this response, which constitutes a self. Our bodies are parts of our environment; and it is possible for the individual to experience and be conscious of his body, and of bodily sensations, without being conscious or aware of himself. (Mead 1934b: 171)

5 In concordance with Heinz Werner's (1934; 1963) developmental description and move from juvenile syncretic, sensorial, and affective (implying faster and unreasoned limbic processes) processes, to more mature mental states that are discrete, objective and language based. Also Ernest Schachtel's (1959) distinction between an earlier developmental experiential realm dominated by autocentric senses, or the intimate senses of touch, smell and taste, toward, with increased maturity, to an ascending dependency on allocentric or distal senses such as vision and hearing and the mediation of reality through language.

6 I am co-opting the term historicity from its other uses, in semiotics and biosemiotics. Within semiotics itself it has been used as a term used to move away from a decontextualized Saussurean (1916/1983) Synchronic analyses. See page eleven in this work for my own qualified biosemiotic meaning of historicity. 
This interpretation and read of Mead may leave some biosemioticians with a blank stare and perhaps even disappointed. So, to the extent that Mead's consciousness is so dispatched and made to be the unique property of certain types of creatures who do valuative communicative processes, it may rub the wrong way and upset biosemioticians and other students of consciousness who have described consciousness as ubiquitous in the animal kingdom (from the inorganic realm to the plant kingdom and beyond), present from the beginning in the origin of our universe, albeit in some minor quality form, or teleologically evolving toward a certain type of universal presence-consciousness, thus opening the door for moralizing or simply imagining the random adaptation of species as guided development toward a god-like state (Davis 1999).

But Mead "saves the day," in a manner of speaking, because he makes his concept of sociality the genesis and integral component of his biosemiotics, if we can begin to be comfortable describing his semiotics as such. Since sociality is, simply put, forced relatedness, or forced semiosis, which appears early in evolution, and is present at the lowest levels of organismic interaction ${ }^{7}$, he is admitting to the primacy of semiosis, from the beginning, while pointing out that we must be mindful of the obvious qualitative differences that arise when different types of creatures achieve different possibilities of relatedness with their respective umwelten. The highest degree of relatedness that humans understand and can empirically test in nature is the sociality he terms, The Realm of Continued Emergence. Only creatures like we who can meaningfully evaluate our actions in the face of a changing environment and ask ourselves, in our own minds, the question, "What are my acts in relation to a changing environment?" or "What could these acts mean in possible X or Y environments?", can achieve this sort of specialized consciousness.

Finally, and perhaps more importantly, Mead is naming and describing this particular set of ideas with the intention of determining what the real existential moment is for any creature. Does existence lie in the past? Does it lie ahead in the future? Mead's answer is nay, relatedness with an umwelt is always in the present, even though historicity, in the way of habits and learned responses, predisposes a

7 Mead specifically mentions a semiosis of hormonal functioning, "There is in the physiological system such a system of communication carried out by hormones." (The Philosophy of The Present, p. 83.) 
certain biased attitude with respect to accommodating a new umwelt. As Arthur Murphy (1932) interprets Mead, "The present is the locus of reality". But humans, who supposedly live in The Realm of Continued Emergence, are ductile in their accommodability to novel situations and in their possibility/opportunity to derive, constantly, new meanings from most changing environments, and to re-apply them. Not only do we inhabit this singularity of the present, but also, according to Mead's own read and interpretation of relativity theory, we could inhabit several umwelten at the same time. In order to explain how this comes about he employs the functionality of passing as the mechanism allowing this multiple referentiality.

I will turn next to Mead's idea of passing, the mechanism through which an organism moves from umwelt to umwelt while preserving the integrity of crucial aspects of its historicity, and at the same time, adapting its historicity to new experiential realms.

\section{Passing}

It may be easier to summarize the interpretative and organizational function of passing using a simple organism and example. A simpler organism such as a cicada (or, e.g., Uexküll's example of relatedness in 'flowers and girls', see Uexküll 1992; 1926; 1982), or any other similar creature is forced to relate semiotically with a (finite) set of umwelten and could organize each new circumstance by means of habits (which I have replaced here with a new sense of historicity to include both learned behaviors and instinctual repertoires of responses, and conscious-voluntary and unconscious-involuntary responses - a probability value of the likely actions we expect to see displayed given the sum total, or the appropriate dispending, of one or more of these factors), by somehow recognizing and reacting to a new circumstance, and finally by accommodating the new umwelt of experience.

Assuming that the cicada has a sense of the limits of its own bodyshell, of self-enclosure or any sense of being an entity with a certain set of constant peculiarities and functions (it feeds, it flies, it fights, it mates), then it can adapt to the new forced semioses with historicity. Historicity itself facilitates the passing from umwelt to umwelt although historicity itself does not guarantee that a cicada (or any 
other organism) will be able to accommodate a new situation in a manner that maximizes survival. If the cicada was a more complex organism, an organism with a mind, it might even be able to also select and organize the new umwelt so its historicity acquires new meaning in the novel circumstance. But alas, the mostly ergodic cicada is enslaved to play only limited sets of expected roles. Passing, according to Mead, from umwelt to umwelt, includes all of these functions and it allows an organism a higher probability of not only interpreting the new scenario appropriately, but also of deriving new meanings that can then be transferable, to use a behaviorist and cognitive concept, into new environments-umwelten-circumstances.

From previous sections then, it follows logically that conscious beings who possess multiple referentiality, due to their social expertise and the ability to simulate the other many times over within their own minds, are able to transmute historicity into practically anything they need to in order to manage the new circumstance. To them is bestowed the greatest prize of all: to privately, in their own minds, think up umwelten ad infinitum, or ad nauseam if you prefer, and relate to these even when these worlds do not materially exist. For example, imaginary umwelten could conceivably extend into complex dreaming life, particularly into a semiotics of lucid dreaming, when consciousness reappears and can be manipulated at will while exploring uncanny dreamscape semiosis (Conesa 2003; 2004).

For now, let us accept the idea that multiple referentiality, to some degree or another, is achievable by most members of a given species endowed with consciousness and that this is generally a good thing. This is a big assumption, but if true, then Mead asserts that we are now in the position to inhabit multiple frames of references at once and that only conscious organisms that exist in The Realm of Continued Emergence can do so.

That is, a human being, and only a human being, can imagine being a passenger inside an imaginary rocket ship traveling at the speed of light and, simultaneously, a stationary person who remains on the face of the earth watching the rocket rise and then disappear. The fact that we can inhabit both perspectives (umwelten) is shown by the fact that many individuals of our species, for example Einstein, are (were) able to imagine such a dual perspective or circumstance at the same time. Mead did not say this, but if he could, he would say that relativity theory can only be a product of a conscious mind, and that in 
passing from one frame of reference to another, this mind is also able to maintain or retain so much historicity as to be able to make both realities part of their real present. Mead also uses examples more mundane than the one given above, including the meaning of a dollar to several individuals. He cites, for example, that even though the first two individuals may be seeing the value of a dollar in a restricted sense, and each from their own unique perspective, a third individual can incorporate both perspectives and synthesize, to boot, a novel perception that gives him the monetary or investment advantage. Suffice it to say, for the purposes of this examination, that maintaining multiple referentiality while passing from umwelt to umwelt confers upon the conscious organism a tremendous advantage and opens the door to unimaginable possibilities, that even though removed from the utility of the present, allows semiosis to overreach and, if lucky, make possible umwelten that previously did not exist. By the way, his position is also an argument against absolute incommensurability, within a conscious species' passsing (Kuhn 1983; Feyerabend 1987), since no probable umwelt is truly extant from this sort of advanced consciousness. Despite Mead's convincing and interesting elaboration (realistically speaking, only a smaller number of individuals belonging to a conscious species might be able to experience full-blown multiple referentiality as in the case of Einstein's insight ${ }^{8}$ ) of the real experience of inhabiting several perceptual spaces, simultaneously, this idea does not explain passing itself, at least not without first determining what bridges are (can be) built between probable umwelten that renders null the idea of two truly incommensurable environments. In the next section, I will try to show how the transferability of these elements, as explained by Mead, is not sufficient to track the successful passing from umwelt to umwelt and that SMT already has a vocabulary that handles these passings. In short, passing as explained by Mead seems to be dependant mostly on whatever cognitive or general talents are available to an organism thus lessening the potentiality, in the electrical sense, of a sort of impossible existential relativism that would prohibit movement and adaptation to a novel umwelt.

8 One person's multireferential insight is all it takes. After the fact, an entire culture can benefit from this insight without a thorough understanding of this accomplishment or what it 'really' means. 


\section{The elemental currency of "passing": A pansemiosis or heuristics of matricial doings}

The reader is referred to a more complete treatment of the original version of SMT (Conesa 1999), and to a relatively more recent and succinct version of the same ideas (Conesa 2001) that present the following and more basic existential, adaptational arguments in a thumbnail sketch. The following basic positions have been changed here to address the Mead discussion presented thus far. These propositions, if you like, are as follows:

(1) Living organisms (and other "things") are matrices". Therefore, in living entities, Energy, Safety, and Possibility need and functions, and their feedback interactions, are consubstantial giving rise to the emergent dynamics of what I define as matricial activity, or a matrix as an integral entity.

(2) As matrices 'we' embody Energy, Safety and Possibility needs and the umwelt provides sensorially and perceptually comprehensible sets of invariant information that can then be turn into affordances (Gibson, 1979). Affordances can then be interpreted as providing these basic matricial needs. This is why SMT is a biosemiotic theory, because it takes into account that a seamless and pervasive existential complementary exists between the object, the sign, and the interpreter which provides the basic sustenance for all meanings. This existential complement and yoked-in triad permeates and predates all sign systems, and all sign transactions. The historicity of an organism, partly programmed by its own genome and partly learned, is fundamentally and existentially the historicity of Energy, Safety and Possibility needs however this historicity is played out in the diverse attempts to deal, and to eke out an existence.

(3) Organic (maenadic-animals and ensilic-plants matrices) matrices have evolved countless metabolic, physiological, behavioral, and mental adaptations to express and complement these matricial needs by first reacting, responding, identifying or labeling objects in any

9 In actuality, and biosemiotically speaking, anything could be a matrix as long as it meets the definitional requirements of even being perceived as one. The idea of God is therefore a matrix and so is currency. 
environment that they encounter as resources to meet these needs. Thus, a biosemiotic structure might be derived from a description, understanding, and prediction of these interactions. I have argued that the topological mathematics of Kurt Lewin's (1936 and 1939) Life Spaces may be a computational first step to learn something about these interactions, if only Lewinian terms are replaced with matricial functionality and jargon.

(4) All human knowledge, in all areas of interest, is an attempt to describe, understand, and/or predict how these matricial interactions occur. Incommensurability across these fields exists only insofar as lower level, technical jargon is used to define (without interdisciplinary effort) their phenomena of interest, a continua of biosemiosis ${ }^{10}$.

(5) The summary of this quest and understanding agrees with Systems Theory somewhat in that life transactions are all ecological (systemic). However, there are limitations to Systems Theory addressed by SMT (Conesa 1999; 2001).

(6) To understand the 'system' is to have a science that predicts how the system might behave. This understanding must also be semiotic as others intuited, pointed out and corrected (Maturana, Varela, 1980; 1987). In this sense, a good 'life' theory, psychological, biological, economical, etc., describes significant matricial events that occur in a system and is able to make predictions about these.

(7) Ecological Ethics, or Ecoethics, is an emergent necessity and the backbone describing the manner and nature of these relationships/ interactions insofar as development proceeds from one smaller and physiologically restrictive matrix, to a larger one, and yet to a larger one (zygote, womb, mother, family, school, community, nation, planet, etc.). The passing from simpler to increasingly complex umwelten, if it is to succeed, must include a see-through universal

10 By the way, I do believe that incommensurability is pervasive for less complex organisms with respect to more complex ones to the extent that mind is absent in the former. An insect, for example, cannot understand the concept or idea humanness; but an intelligent dog, for example, an organism with a fairly complex mind, can sympathize in many non-commensurable moments with its human partner. 
biosemiotics rooted in more or less easy to interpret, or easy to learn signs that assists the 'becoming' of an organism during its ontogenesis. To this end, human organisms (and other species) invent "rules" of ecological engagement that allow them to maximize potential within reason, without destroying the delicate balance of these tenuous relations. Sometimes an organism ignores these ethical rules in order to maximize matricial procurements (to dysfunctionally, in the sense of ignoring the consequences to its ecological setting, monopolize) it does this at the developmental or matricial detriment of others and while causing injury to an ecosystem. Biosemiotics, in the end, has to deal with ethical questions, and Mead's passing, specifically, must include a notion of functional limits found in each umwelt lived. $^{11}$

(8) Life processes allow an almost infinite number of strategies for achieving organismic potential; but at the root of these endeavors are the matricial beta elements: Safety, Energy, and Possibility.

(9) Semiotic Matrix Theory specifies the way in which biosemiosis can be structured through an empirical program that tests the ecological validity of these interactions that then can be applied to any study that examines systems.

(10) Encapsulated physical bodies are 'simply' the phenotypic expression of these matricial forces encountering and surviving diverse environments. Moreover, both genomic and phenotypic adaptations and developments are servicing, through simple and complex feedback systems, the achievement of a matricial homeostasis. Being that all organic systems are being drafted, consciously or not, toward this end, matricial integrity, then the entire enterprise of merely surviving and/or meaningful existence is participating in a common ground of 'being'. If so, then surely a biosemiosis dominates from the bottom up and anything else we can explain or discover about semiosis is really a

11 Joseph Chilton Pearce (1971 and 1977), first laid out the developmental sequence just mentioned, and proposed the ideas that are foundational to SMT. Even his idea and use of the term 'matrix', used in this developmental sense, makes a better case for this progression than I am making here. I encourage readers to revisit his thought provoking and controversial book, Magical Child (1977). 
forced relatedness or a forced semiosis and sociality that it is always matricial at its core.

(11) The historicity of an organism, any system, however complex, colorful or idiosyncratic, makes an explicit or an implicit reference to matricial necessities. It is an existential situation, from the bottom up and in reverse, where a pervasive (and/or perverse if you wish) biosemiotic field is, in my opinion, inescapable. In its new formulation, and contrasted to Mead's ideas, I call it a hermetic biosemiosis.

If the above points can be accepted at face value, at least for the purposes of this aim, namely, to elucidate the problem ${ }^{12}$ of passing from one frame of reference to another while maintaining a principal and primordial existential objective, then the following might make more sense. The cicada, an organism with limited 'mind' and thus with limited frames of references, as well as a human being, an organism who inhabits the multi-referential realm of continued emergence, in moving from one existential circumstance to another, must both maintain a common denominator and heuristic that transcends the 'many flavors' of speciation, the exuberant display of multiplicity of signs, and the many opportunities for passage from umwelt to umwelt. In addition to all transferable commodities that assist the passage from one frame of reference to another (including: instinctual responses; acquired cognitive skills; cultural and genetic adaptations; the grandiose 'self'; short-term or long-term learning; or any other bodily or mental propensities that one may wish to even remotely associate with my term transferable commodity) and give life, purpose, and meaning to their expression is an ontological semiosis that reads a universal matricial manual before commencing to select, organize and then get cozy in a new frame of reference. This thoroughly enveloping ontosemiotic baseline, at least a facilitator of passing, is even more crucial for organisms who are mentally ductile in multiple referentiality, because they have an even greater need for an ontological compass, given that some automaticity of responding can now be supplemented or taken over altogether by the 'little voice inside the head,' and given that the little voice may be sometimes wrong.

12 I see it as and call it a problem, Mead may have not thought of it as a problem. His writings assume and are hopeful that the generalized other would be passport enough (pun intended) between umwelten. 
When the 'little voice in the head' is wrong, along with the rest of the little voices inside the heads of the society from which individual Self-consciousness emerges, then we might be partaking of dysfunctional semiosis. As Erich Fromm (1955) said, "That millions of people share in the same forms of mental pathology does not make those people sane." The next section presents the position that deep ecological and green psychological movements put forth, namely the necessity of re-establishing an authentic and long neglected biosemiosis, at the cultural level, absence which is the cause of individual unhappiness and illness, as well as a societal disintegration.

\section{Mead, SMT, and ecological ethics}

The apparent existential freedom of continued emergence also comes with a social and psychological price to pay (Fromm 1955) and a duty to ecological ethics (an ecological morality). That is, to deep ecologists (Naess 1973; Sheppard 1973; Naess 1979; Sheppard 1982; Devall, Sessions 1985) and green psychologists ${ }^{13}$ (Roszak 1979; 1992; Metzner 1971; 1999) who see BEING, and in particular healthy BEING, as predicated in the natural and specifically in the wild, such creative semiosis could turn out to be a dysfunctional semiosis, precisely because it may deviate and stray into purely fictional and aberrant semiosis (culturally driven or subjectively creative, both types could be delusional in the sense that Erich Fromm stated in an earlier passage) from an original telluric and biosemiosic ground (Sheppard 1973; 1982). As Paul Sheppard brilliantly demonstrated (an idea that continues to be debated), "the tender carnivore" has been domesticated by an agricultural and deviant text and semiosis and therefore has long ceased to be in harmony with ancient patterns and is no longer socially or mentally sound. But the above criticism is not new, and even before many were blaming modernism as another noninclusive 'ism' that lacked this or that, or that was not addressing the needs of this or that group, a modernist voice and philosopher, George Santayana, recognized in a speech that was later to be printed, that

13 Peter Kropotkin's (1914) name must be added as a precursor to this list of ecopsychologists (Roszak 2001) for he contributed, to the budding concept of an 'ecosystem,' being dependent on mutual, interspecies aid. 
something was wrong with European philosophy with respect to ecological ideas when he said:

A Californian whom I had recently the pleasure of meeting observed that if the philosophers had lived among your mountains [California mountains], their systems would have been different from what they are. Certainly very different from what those systems are which the European genteel tradition has handed down since Socrates; for these systems are egotistical; directly or indirectly they are anthropocentric, and inspired by the conceit notion that man, or human reason, or the human distinction between good and evil, is the center and pivot of the universe. That is what the mountains and the woods should make you at least ashamed to assert. (Devall 1985: 46)

It is not certain whether the "Californian" Santayana was referring to was none other than the Scott naturalist and founder of The Sierra Club, John Muir. But William Devall (1985) certainly thought that this modernist voice was the beginning of a new era when he writes, "[the speech at The University of California at Berkeley]...was a historical turning point in the development of the contemporary search for an alternative worldview and an environmental ethic that would not be subjectivist, anthropocentric, and essentially materialistic". Devall's statement is also an example of and recognition that contrary to stereotypical descriptions of a particular age, each epoch conveniently invents derogatory as well as admiring terms for other epochs while rewriting their own history, and in so doing, highlights or ignores text when this text is either beneficial or contradictory of their stated positions, respectively. Thus every epoch is more or less modern or more or less dark in comparison to another. Santayana's text speaks of a sentiment that was not really completely lost in European thought (Nash, 1982; Devall, Sessions 1985). After all, John Muir, a Scott, who migrated to North America, hiked and fell in love with this wilderness and pushed "American" politics and psyche from the romantic ideal of nature toward the observation of its intrinsic right to be sustained and thus protected.

Interestingly, both William Devall (1985) and Erich Fromm (1955) go further into history to bring back another voice, Spinoza's, who can validate their shared thesis that a particular collection of dysfunctional meme-texts can be admitted as normal by a given culture or at least tolerated to a certain degree. Erich Fromm (1955: 24) quotes a passage from Spinoza's Ethics (IV) that it is worth examining, 
Many people are seized by one and the same affect with great consistency. All his senses are so strongly affected by one object that he believes this object to be present even when it is not. If this happens while the person is awake, the person is believed to be insane...But if the greedy person thinks only of money and possessions, the ambitious one only of fame, one does not think of them as being insane, but only as annoying; generally one has contempt for them. But factually greediness, ambition, and so forth are forms of insanity, although usually one does not think of them as illness. (Spinoza: 44)

I share the above passage to suggest that any predisposed or learned behavioral singularity that it is not ecologically edifying, a fetish, is a form of illness. There is at least a logical implication in Mead's yoking of 'self' with 'society' (Mead 1932), or the social, that allows the conclusion that the ethical clarification within the self of what is right or wrong (even sane or not in Fromm, 1955) emerges from the semiosis between Self and society:

Since society has endowed us with self-consciousness, we can enter personally into the largest undertakings which the intercourse of rational selves extends before us. And because we can live with ourselves as well as with others, we can criticize ourselves, and make our own values in which we are involved through those undertakings in which the community of all rational beings is engaged. (Mead: 90)

If so, it is equally probable that: a 'self', originating within the social realm as it does, while intuiting, apprehending and utilizing its universal meme-text, is capable of realizing that his polis, the cultural semiotic world that gave origin to the 'little voice' inside his head, is thoroughly corrupted and so is the text inside his head. This is the beginning of healing for the above-mentioned deep ecologists and green psychologists.

If we are creatures of continued emergence that can grasp universals, above and beyond the very social matrix that gave us the power to so do, then we can also fix the corrupted meme-text. In attempting to do so there is, first, a need to describe, biosemiotically, how this dysfunctional, industrialized or agricultural, text might be looping into nonsense or even illness, looping into perversion and narcissism, and moving faster and farther from a true concept of community, and intimation with each other as umwelten and with wild nature as the most authentic backdrop for these intimations. As hinted at earlier, any of these are dysfunctional social loops, or fetishes, 
because they deny identification with a larger ecology hyper selecting, thus reducing, a larger potential field of biosemiosis. For example, who would argue with the thesis that mass, ravenous consumerism, an inclination toward the artificial, and a reduced ability to tolerate the inclemency's of bad weather make for a stronger self or a more factual biosemiosis?

Deep ecologists as well as green psychologists are awaiting a more earnest effort and dogged contribution from our lot. Without our concerted ensemble contribution dictionary entries such as the one I shared at the beginning of this text, "Tarantula: an insect whose bite is only cured by musick [sic]", in another form (such as the still prevalent bad habit of avoiding using the word 'animal' to designate humans) will continue as examples of fetish, or anthropocentric semiosis.

To conclude this section, it is fair to say that the biosemiotic intellectual paradigm, with the assistance of other ecological (deep and shallow) disciplines, if it chooses to lead in that direction, could actively be involved in these deep ecological discussions and build a more inclusive semiotics where biosemiosis is not limited to the signin-nature, but more broadly puts forward an authentic effort in examining the consequences of the absence of the original sign in the present human text. Even though there are already noteworthy successes of this kind of extended a more inclusive biology within biosemiotic writings (Emmeche, Hoffmeyer 2001; Kull 1998), the deep ecological sentiment in biosemiotics is not well covered. Also, a recent review of theories of emergence (life, consciousness, biosemiotics) did not list Mead as a reference. I only mention this because, at least to me, it seems important and even logically necessary to connect theories of emergence, biosemiosis with those of ecological ethics.

\section{Discussion}

Thus far, I have argued that in phylogenic and ontogenetic forms of 'becoming', and while passing from umwelt to umwelt, matricial truth and aims are reiterated. Ecological ethics are also obligated if we agree with Joseph Chilton Pearce's developmental model (Pearce 1977). This fractal iteration of BEING grounded on matricial neces- 
sities, or another biopansemiosis ${ }^{14}$ that could replace it, is falsifiable at face value, if we consider the following, as George Santayana (1955) would say, brute facts. As negative examples, if an existential biopansemiosis did not exist, of the sort described by SMT, then any sufficiently distinct frame of reference would be truly incommensurable, thus intraversable and impassable, within (and without) the spaces of self and cultural semiosis. Passing would be, if not impossible, extremely difficult, reducing the range of semiosis we observe in the life (and historicity) of this planet to indescribable and unthinkable senseless events. Logically, speciation would not be possible, assuming that we describe speciation semiotically, as passing from a vanishing set of existential accommodations to another emerging set of significantly different existential accommodations, in varying degrees of difference and success.

Moreover, if passing is also understood as intra-species accommodation, interpretation or deployment of instinctual behaviors, and some biosemiotic mechanism did not facilitate the functions, then every organism would go hungry and starve to death for no apparent reason. Copulation, as an example of primal forced relatedness or forced semiosis would be a bizarre undertaking, or would not take place at all. Equally, without a biosemiotic set of guidelines there would be no need for nests, burrows, or houses with thermostats and fences, or the distinction between enemy and friend. Bluntly put, there would be 'nothing' instead of 'being'.

To conclude, focusing on the sign, myopically; on human culture and semiosis, myopically; on the little sounds we make with moving lips, myopically; on the little sounds that birds make when they sing, myopically; on poetry, myopically; we risk missing a grander biosemiotic phenomenon: everything does the same things except a little bit differently. ${ }^{15}$

It is quite probable, as Mead intuited and defended, that only social organisms who also achieve multiple referentiality are in a position to

14 SMT traces the existential doings of organic matter and of life to inorganic, energetic beginnings. Thus, in this more inclusive sense, the terms pansemiosis or biopansemiotic are used.

15 As my grandmother Carmen Sevilla Perez from Cadiz told my Catalan mother, Montserrat Sevilla de Conesa, born in Paris, and my mother continually reminds us when we unjustly, stereotypically, compare the ways and customs of diverse peoples and countries: "En todas partes del mundo se comen habas", or "Everywhere, everyone eats [some sort of] beans. " "Just a little bit differently," I add. 
maintain so many points of view at once as to begin to apprehend universals. This capacity may sometimes be simply a wishful subjective projection rather than the discovery or intimation of an actual and bona fide universal or natural habit. Sometimes this capacity simply produces mental aberrations and illness. But sometimes this capacity pays off, substantially, and produces an explanation that incorporates extant frames of reference. However, depending on how extant the new frame of reference is, it may or may not be thoroughly incorporated into human culture as a semiosis of mental associations and meanings. Most people, I would venture, do not understand basic principles in physics, psychology, chemistry or biology even though the technologies and ideas that spun from these fields are routinely employed by all of us. This lack of in depth understanding does not mean that these fields are incommensurable from each other, or that the average person cannot grasp the essential insights found in all of these fields. But, practically speaking, the average person simply does not have the time to be so comprehensive or inclusive, or he/she simply chooses to specialize in one field at the exclusion of other fields.

Thus, an existential drive can be summed up by the following questions: Can I make a 'living' today? If so, then: What basic elements gathered from raw reality do I employ to even begin to make a 'living'? And, how many of these elements are, biosemiotically speaking, significantly foundational and enduring so that I can continue making a living tomorrow? If a given organism can achieve the Realm of Continued Emergence as an added bonus, then life may seem either more pleasant and interesting or twice as horrifying, depending on one's myopic frame of reference. But through happy dreams or through nightmares, one can be certain that everything does the same things, except a little bit differently. Sociality as forced relatedness, or forced semiosis, and, sociality as the driver and engine for semiosis, does so: it makes sure we tug the same ontology along, always matricial at its core. 


\section{References}

Bateson, Gregory 1979. Mind and Nature: A Necessary Unity. New York: Bentam Books.

Bragg, Melvyn 2003. The Adventure of English: The Biography of a Language. London: Hodder and Stoughton.

Byrne, Richard W.; Whiten, Andrew (eds.), 1988. Machiavellian Intelligence. Oxford: University Press.

Byrne, Richard W.; Tomasello, Michael. 1995. Do rats ape? Animal Behaviour 50: 1417-1420.

Colby, Anne; Kohlberg, Lawrence; Kauffman, K. 1987. Theoretical introduction to the measurement of moral judgment. In: Colby, Anne; Kohlberg, Lawrence, The Measurement of Moral Judgement (Vol. 1). Cambridge: Cambridge University Press.

Conesa, Jorge 1999. Ecological Outcome Psychological Theory: Application of Human Developmental Theories to Other Scientific Fields. New York: Forbes-Thomson Learning Publishing.

- 2001. A Semiotic Metalanguage Based on Existential Ontologies. Presented at the International Summer Institute for Semiotic and Structural Studies in Imatra, Finland. (June 10-15, 2001.)

- 2003. Sleep paralysis signaling (SPS) as a natural cueing method for the generation and maintenance of lucid dreaming. Presented at The 83rd Annual Convention of the Western Psychological Association, May 1-4, 2003 in Vancouver, BC, Canada.

Conesa-Sevilla, Jorge 2004. Wrestling With Ghosts: A Personal and Scientific Account of Sleep Paralysis. Pennsylvania: Random House-Xlibris

Davies, Paul. 1999. The Search for the Origin and Meaning of Life. New York: Simon and Schuster.

Dennett, Daniel C. 1983. Intentional systems in cognitive ethology: The "Panglossian paradigm" defended. Behavioral and Brain Sciences 6: 343-390.

- 1991. Consciousness Explained. Boston: Little and Brown.

Devall, William; Sessions, George 1985. Deep Ecology: Living as if Nature Mattered. Layton: Peregrine Smith Book.

Emmeche, Claus; Hoffmeyer, Jesper 1991. From language to nature: the semiotic metaphor in biology. Semiotica 84(1/2): 1-42.

Feyerabend, Paul K. 1987. Putnam on Incommensurability. London: Verso.

Fromm, Erich 1955. The Sane Society. New York: Holt, Rinehart \& Winston Printing.

Gibson, James J. 1979. The Ecological Approach to Visual Perception. Boston: Houghton-Mifflin.

Goleman, Daniel 1995. Emotional Intelligence: Why Can it Matter More than IQ? New York: Bantam Books.

Hoffmeyer, Jesper 1996. Signs of Meaning in the Universe. Bloomington: Indiana University Press.

Harries-Jones, Peter 1995. A Recursive Vision: Ecological Understanding and Gregory Bateson. Toronto: University of Toronto Press. 
Heyes, Cecilia M. 1993. Anecdotes, training, trapping, and triangulating: Do animals attribute mental states? Animal Behaviour 46, 177-188.

- (1998). Theory of mind in nonhuman primates. Behavioral and Brain Sciences 21(1): 101-134.

Kilpinen, Erkki 2002. A neglected classic vindicated: the place of George Herbert Mead in the general tradition of semiotics. Semiotica 142: 1-4.

Kohlberg, Lawrence 1981. Philosophy of Moral Development. New York: Harper and Row.

Kropotkin, Peter 1914. Mutual Aid. New York: Knopf.

Kull, Kalevi 1998. On semiosis, Umwelt, and semiosphere. Semiotica 120(3/4): 299-310.

Kuhn, Thomas S. 1983. Commensurability, Comparability, Communicability. In: P.D. Asquith and T. Nickels (eds.), PSA 1982: Proceedings of the 1982 Biennial Meeting of the Philosophy of Science Association, Vol. 2. East Lansing: Philosophy of Science Association.

Lewin, Kurt 1935. A Dynamic Theory of Personality. New York: McGraw-Hill.

- 1936. Principles of Topological Psychology. New York: McGraw-Hill.

- 1939. Field theory and experiment in social psychology: concepts and methods. American Journal of Sociology 44: 868-897.

- 1951. Field Theory and Social Science. New York: Harper.

Maturana, Humberto R.; Varela, Francisco J. 1980. Autopoiesis and Cognition: The Realization of the Living. Dordrecht: D. Reidel.

- 1987. The Tree of Knowledge. Boston: Shambhala.

Mead, George H. 1934a. The Philosophy of the Present. Chicago: The University of Chicago Press.

- 1934b. Mind, Self, and Society: From the Standpoint of a Social Behaviorist. Chicago: The University of Chicago Press.

- 1964 [1908]. The philosophical basic of ethics. In: Reck, A. J. (ed.), Selected writings: George Herbert Mead. Chicago: The University of Chicago Press.

Metzner, Ralph 1971. Maps of Consciousness. New York: Collier-Macmillan.

- 1999. Green Psychology: Transforming Our Relationship to the Earth. Rochester: Park Street Press.

Naess, Arne 1973. The shallow and the deep, long-range ecology movements: A summary. Inquiry 16: 95-100.

- 1979. Self-realization in mixed communities of humans, bears, sheeps, and wolves. Inquiry 22: 231-241.

Nash, Roderick 1982. Wilderness and the American Mind, 3rd ed. New Haven: Yale University Press.

Pearce, Joseph C. 1971. The Crack in the Cosmic Egg: Challenging Constructs of Mind and Reality. New York: Pockets Books.

- 1977. Magical Child. New York: Bantam Books, Inc.

Peirce, Charles S. 1966. Selected Writings. New York: Dover

Piaget, Jean 1932. The Moral Judgment of the Child. New York: Harcourt Brace Jovanovich.

- 1972. Intellectual evolution from adolescent into adulthood. Human Development 15: 1-12. 
Premack, David 1983. Animal cognition. Annual Review of Psychology 34(Jan.): 351-362.

Premack, David; Woodruff, Guy 1978. Does the chimpanzee have a theory of mind? Behavioural and Brain Sciences 7: 515-526.

Roszak, Theodore 1979. Person-Planet. New York: Anchor Press.

- 1992-2001. The Voice of the Earth. New York: Simon \& Schuster.

Santayana, George 1955. Skepticism and Animal Faith. New York: Dover.

Saussure, Ferdinand de 1983 [1916]. Course in General Linguistics. (Harris, Roy, trans.) London: Duckworth.

Schachtel, Ernest G. 1959. Metamorphosis. New York: Basic Books.

Sheppard, Paul 1973. The Tender Carnivore and the Sacred Game. New York: Scribners.

- 1982. Nature and Madness. San Francisco: Sierra Club.

Uexküll, Jakob von 1926. Theoretical Biology. New York: Harcourt, Brace \& Company.

- 1982. The theory of meaning. Semiotica 42(1): 25-82

- 1992 [1934]. A stroll through the woods of animals and men: a picture book of invisible worlds. Semiotica 89(4): 319-391.

Vygotsky, Lev S. 1934. Thought and Language (Kozulin, A., trans.) Cambridge: MIT Press.

Werner, Heinz 1978 [1934]. The unity of the senses. In: Barten S. S.; Franklin, M. B. (eds.), Developmental Processes: Heinz Werner's Selected Writings (Vol. 1). New York: International Universities Press.

Werner, Heinz; Kaplan, Bernard 1963. Symbol Formation. New York: John Wiley.

Wiley, Norbert 1994. The Semiotic Self. Chicago: University of Chicago Press.

Whiten, Andrew 1996. When does smart behaviour-reading become mindreading? In: Carruthers, P.; Smith, P. K. (eds.), Theories of Theories of Mind. Cambridge: Cambridge University Press.

Whiten, Andrew; Byrne, Richard W. 1988. Tactical deception in primates. Behavioral and Brain Sciences 11: 233-273.

Wiener, Norbert 1965. Cybernetics or Control and Communication in the Animal and the Machine. Massachusetts: The MIT Press.

Wilson, Edward O. 1984. Biophilia: The Human Bond with Other Species. Cambridge: Harvard University Press.

- 1998. Consilience: The Unity of Knowledge. New York: Random House.

Woodruff, Guy; Premack, David 1979. Intentional communication in the chimpanzee: The development of deception. Cognition 7: 333-362. 


\section{Область продолжающего творчества: семиотика Джорджа Герберта Мида и ее результаты в биосемиотике, теории семиотической матрицы и экологической этике}

Данное исследование обращает внимание прежде всего на поворотные идеи Дж. Г. Мида о социальности, сознании и коммуникации. Мидовское понимание социальности как принудительного отношения или принудительного семиозиса, который появляется уже на раннем этапе эволюции и проявляется в простых системах, гарантирует ему место основоположника среди биосемиотиков. К идеям Мида принадлежит и описание мультиреференциальности, которая свойственна социальным организмам (это связано с его идеей обобщенного другого), позволяя сравнительно легко переходить из одного умвельта в другой. Хотя широкое понимание Мидом семиозиса звучит убедительно и соответствует принципам современной семиотики (и биосемиотики), все же в нем отсутствует удовлетворительное объяснение того, каким образом организмы, обладающие сознанием, способны переходить на новые основания референции. В развиваемой автором “теории семиотической матрицы” пансемиозис описывает в качестве функции “перехода" фальсифицируемые экзистенциальные и когнитивные методы эвристики распознавания потребностей в энергии, забот о безопасности и благоприятной возможности. Не каждый семиозис сам по себе хорош, как хорош не каждый текст. Так как наш вид отходит от первобытного семиозиса и взаимозависимости, то историчность (пусть и изобретая послушно синтетический семиозис или капризные умвельты) сталкивается с последствиями экологической реальности и слишком антропоцентрического текста.

\section{Jätkuva loomingu valdkond: \\ George Herbert Mead'i semiootika ja selle tulemid biosemiootikas, semiootilise maatriksi teoorias ja ökoloogilises eetikas}

Käesolev uurimus George Herbert Mead'i semiootika teemal pöörab peatähelepanu ta pöördelistele ideedele sotsiaalsusest, teadvusest, ja kommunikatsioonist. Meadi arusaam sotsiaalsusest kui sunnitud suhestatusest, või sunnitud semioosist, mis ilmub evolutsioonis varakult ja avaldub lihtsais süsteemides, garanteerib talle rajaja koha biosemiootikute hulgas. Nende Meadi ideede hulka kuulub multireferentsiaalsuse kirjelda- 
mine, mis on omane sotsiaalsetele organismidele (seotult ta üldistatud teise ideega), võimaldades üleminekut ühest omailmast teise suhteliselt kergelt. Kuigi Meadi avar semioosi mõiste on veenev ning vastavuses praegusaegse semiootikaga (ning biosemiootikaga), siiski puudub selles rahuldav seletus sellele, kuidas teadvusega organismid suudavad üle minna uutele võrdlusalustele. Autori poolt arendatav 'semiootilise maatriksi teooria' kirjeldab falsifitseeritavaid eksistentsiaalseid ja kognitiivseid heuristikuid, et eristada "ülemineku" funktsioone 'energeetilisteks eeldusteks', 'kindlustatuseks' ja 'võimaluseks'. Samuti, teistsugust tüüpi loovus, ökoeetika, on biosemioosis peituv konstant. Mitte iga semioos pole hea, nagu pole hea mitte iga tekst. Kuna meie liik liigub eemale ürgsest biosemioosist ja vastastikusest seotusest, siis ajaloolisus, küll kuulekas leiutamaks sünteetilist semioosi või tujukaid omailmu, põrkub ökoloogilise reaalsuse ja üleliia antropotsentrilise teksti tagajärgedega. 